\title{
A unified molecular mechanism for the regulation of acetyl-CoA carboxylase by phosphorylation
}

Jia Wei ${ }^{1}$, Yixiao Zhang ${ }^{2}$, Tai-Yuan $\mathrm{Yu}^{3}$, Kianoush Sadre-Bazzaz ${ }^{1}$, Michael J Rudolph ${ }^{1}$, Gabriele A Amodeo ${ }^{1}$, Lorraine S Symington ${ }^{3}$, Thomas Walz ${ }^{2}$, Liang Tong ${ }^{1}$

${ }^{1}$ Department of Biological Sciences, Columbia University, New York, NY, USA; ${ }^{2}$ Laboratory of Molecular Electron Microscopy, Rockefeller University, New York, NY, USA; ${ }^{3}$ Department of Microbiology and Immunology, Columbia University, Medical Center, New York, NY, USA

Cell Discovery (2017) 3, 16055; doi:10.1038/celldisc.2016.55; published online 17 January 2017

Correction to: Cell Discovery (2016) 2, 16044; doi:10.1038/celldisc.2016.44; published online 29 November 2016

In the initial published version of this article, we omitted the reference to an earlier paper [1] that showed that phosphorylation on Ser1157 was reduced by $50 \%$ in snfl yeast cells and that the S1157A mutant cells could not grow on media-lacking inositol. The addition of this reference does not affect the results, figures, and conclusion of the paper.

\section{Reference}

1 Hofbauer HF, Schopf FH, Schleifer H et al. Regulation of gene expression through a transcriptional repressor that senses acylchain length in membrane phospholipids. Dev Cell 2014; 29: 729-739.

\footnotetext{
(c) (1) This work is licensed under a Creative Commons Attribution 4.0 International License. The images or other third party material in this article are included in the article's Creative Commons license, unless indicated otherwise in the credit line; if the material is not included under the Creative Commons license, users will need to obtain permission from the license holder to reproduce the material. To view a copy of this license, visit http://creativecommons.org/licenses/by/4.0/

(C) The Author(s) 2017
} 